\title{
Interpretation of Baladeva and Yamunā at Harivamśa 83
}

\author{
Simon Brodbeck
}

\begin{abstract}
In Harivamsśa chapter 83, Kṛ̣na’ brother Baladeva changes the course of the river Yamunā, using his plough. This article reviews previous interpretations of Baladeva's deed by André Couture and Lavanya Vemsani and develops in detail an interpretation briefly proposed by A. Whitney Sanford, whereby the deed is viewed, among many superimposed views, as at some level a sexual assault. This angle is explored in the article in various ways, with close reference to the Sanskrit text. The article includes discussion of the dialogue between Baladeva and the personified Yamunā, Baladeva's connection to plough agriculture, the dynamic between Baladeva and Kṛ̣ṇa, and Vaiśampāyana's commentary on the events.
\end{abstract}

Keywords Balarāma Harivamiśa interpretation $\cdot$ Kṛ̣ṇa $\cdot$ metaphor $\cdot$ plough sexual violence $\cdot$ Yamunā

\section{Introduction}

Most of the Mahābhārata tells the story of the Pāndavas' war against their cousins, which they fought and won because Krșna made them. ${ }^{1}$ That story is told to King Janamejaya, descendant of Arjuna Pāṇụava, by Vaiśampāyana. After the Pāṇụavas have gone to heaven and their story has concluded, in the Harivamís Janamejaya

\footnotetext{
1 This paper was first presented in January 2018 in the Sanskrit Reading Room at the School of Oriental and African Studies in London. I am grateful to the organizers Avni Chag, Karen O'Brien-Kop, and Ruth Westoby; to all the contributors to the discussion on that occasion; to Peter Singer for his blog post (Singer 2018); to Ashok Aklujkar, Laxshmi Greaves, and Doris Meth Srinivasan for later assistance; and to four anonymous peer reviewers.
}

Simon Brodbeck

brodbecksp@cardiff.ac.uk

Department of Religious and Theological Studies, Cardiff University, John Percival Building, Colum Drive, Cardiff CF10 3EU, Wales, UK 
asks Vaiśampāyana to say more about Kṛ̣na and his people the Yādava-Vṛṣnis, and Vaiśampāyana does so.

This article focuses on one chapter of the Harivamśa, one episode, and one incident that invites a sexual-metaphorical interpretation. In this episode, narrated at Harivamśa chapter 83, Krșna's brother Baladeva, ${ }^{2}$ while on a friendly visit to the cowherders in Vṛndāvana among whom he and Kṛ̣na grew up, causes the river Yamunā to change course and come close to him by dragging her with his plough. The passage includes a description of the river as she is being dragged (Harivamśa 83.35-40) and a speech that she makes to Baladeva (83.42-46), asking him to put her back where she was, a request which he refuses.

The salient passage will be presented in full in English translation. Then various interpretations of the incident will be discussed, based on specific pieces of secondary literature. These are a mythological interpretation, a religio-historical interpretation, and two metaphorical interpretations in terms of sexual violence. The nature of interpretation of poetry is that different types of interpretation do not compete but are complementary and cumulative. Indulging and exploring one type of interpretation is not discouragement of other types of interpretation, as long as each avenue of interpretation is close and fair to the text.

The mythological and religio-historical interpretations have their limitations, yet the sexual-metaphorical interpretation is underdeveloped in the literature. Hence, after the literature review, the article fleshes out this interpretation by focusing more broadly on the surrounding Harivamśa narrative about Baladeva and his brother Krṣna, and then more tightly on key passages of Harivamśa 83. The article is speculative, but it encourages and facilitates the sexual interpretation with close reference to the Harivamśa text. Art-historical evidence is not discussed, since, as far as I know, the only surviving artistic representations of this story date to the seventeenth and eighteenth centuries, and most of them are not congruent with the Harivamía version. ${ }^{3}$ Other versions of the story in other texts are discussed only in passing. The focus is upon the Harivamśa version and how it operates within the Harivamśa narrative.

When Krṣna's elder brother Baladeva drags the Yamunā, he is on a visit back to Vṛndāvana after he and Kṛ̣na have left Vṛndāvana and moved to Mathurā.

From infancy, Baladeva and Kṛ̣na lived in the cowherd community (Harivamsśa 49). When they were adolescents, they were taken to Mathurā by Akrūra on the occasion of King Kamsa's bow festival (Harivamśa 68-70), and there they (that is, mostly Kṛ̣na) broke the bow and killed Kạ̣sa's elephant Kuvalayāpị̣̄a, Kaṃsa's wrestlers Cānuūra and Mușțika, and Kaṃsa himself. They were reunited with their father Vasudeva whom Kamsa had been punishing, and Kạ̣sa's previously deposed father Ugrasena was restored to the kingship in Mathurā (Harivamśa 7178). After that, Krṣna and Baladeva went to Avanti to be trained by Sāmdīpani in, among other things, the martial arts (Harivamśs 79), and since returning from

\footnotetext{
${ }^{2}$ Baladeva is called variously Bala, Halāyudha, Rāma, Rauhiṇeya, Saṃkarṣaṇa, etc. Elsewhere in Indian literature he is commonly called Balarāma. Some of the writers I quote call him Balarāma.

3 See, for example, Srinivasan 2008: 93-94, 2016: plate 1. When Baladeva is portrayed with a diminuitive female beside him, she tends to be his wife Revatī (Joshi 1979: 17, plate 28; Asher 1980: plate 220). For iconography of Yamunā and Gañgā, see von Stietencron 2010.
} 
Avanti to Mathurā they have been defending it against repeated attacks from the late Kamsa's father-in-law King Jarāsamdha and his allies. The battle scenes are terrific. Baladeva has fought well against Jarāsaṃdha but has been forbidden to kill him by a voice from the sky (Harivamśa 80-82).

At the start of Harivamía 83, Vaiśampāyana suddenly introduces Baladeva's visit to Vrndāvana: "During this same period, Rāma thought about what had happened among the cowherds, and, with the approval of Kṛ̣na himself, he traveled to the herding station on his own" (83.1). Baladeva is well received and exchanges fond pleasantries with the elders. Then he gets drunk in the forest. This is the scene presented by the passage quoted in extenso below. Baladeva summons the Yamunā to come close to him so that he can bathe. She does not come. He drags her there. When she protests after the fact, he tells her to lump it and be good. He is praised by the cowherders for what he has done (Harivamía 83.50), and thereafter he returns to Mathurā and his brother Kṛ̣na.

Soon after this episode, the Yādava-Vṛ̣ṇis abandon Mathurā and flee to found a new city in Dvārakā. Dvārakā is Kṛ̣na and Baladeva's hometown throughout their mature careers and throughout the story of the Pāṇavas. After Harivamiśa 83 the Yamunā episode is mentioned only once, at 90.17 (discussed below).

\section{The Passage (Harivamı́a 83.18-51)}

While Halāyudha was telling these truths there in the midst of the cowherds, the faces of the cowherd women lit up with pleasure. Then mighty Rāma went into the forest and enjoyed himself (18).

On that occasion, for Rāma, the cowherds brought out the guardian goddess of liquor. They knew the right time and place, and he remembered who he was (19). On that occasion Rāma was away in the forest, surrounded by his relatives, looking like a white cloud, and he drank the drink that inspires drunkenness (20). Then the cowherds brought him various forest treats: lovely fresh flowers and fruits (21), and various tasty foodstuffs, and things whose smells made his heart sing, and masses of lotuses and waterlilies, freshly lifted and picked (22).

His crown was slightly awry on his head with its charming locks, a sparkling earring hung from one ear (23), and with his chest cooled by sandalwood and agarwood paste and draped with forest garlands, Rāma looked like Mount Mandara together with Mount Kailāsa (24). Clothed in dark clothes that looked like fresh clouds, that pale-skinned man radiated beauty, like the moon with a garland of clouds (25). With his plough hanging resting on his serpent coils and his shining club clasped in one hand (26), the supreme strongman, drunk, his face rolling, looked like the lazy and languid moon does at night during the cool season (27).

Drunk, he called out to the Yamunā:

"Great river, I want to bathe. Shapely seeker of the sea, come closer to me, right up here" (28).

Misguided by her feminine nature, she ignored Saṃkarṣana's speech as that of a drunk, and she didn't come to that place (29). Then, inspired by his drunkenness, 
strong and mighty Rāma was vexed. He took his plough in his hand and lowered its tip for dragging (30). Lotus garlands tumbled onto the drinking ground and released their own special pollen-colored fluid from their blossom stores (31).

Keeping its tip lowered, Rāma used the plough to grab the great river Yamunā by the bank and drag her, as if she were a wife straying from her duty (32).

The flow of the river's waters was disturbed, she gathered and poured into pools, and she changed course, fearfully following the path of the plough (33). As the plough pulled her path she followed its crooked impetus like a woman in a state of disorder, trembling in fear of Samkarṣana (34).

Her ripe red lips were the sandy shores of the riverbed, her belt was the line of foam pressed out by the pounding waters, her tell-tale signs were the smiling creatures along her banks (35), her crown was the rough waves, her erect nipples were the brahminy ducks, her limbs were the deep and twisting currents, and her birds and fish were anxious (36). The glances from the corners of her eyes were the geese, her discarded linen clothing was the kans grass, and her tossed locks of hair were the plants on the banks. The flow of her waters was interrupted (37), and the plough scratched the corners of her eyes. The agitated river was like a drunk woman staggering along the royal road (38). The flow of her current was interrupted, and her course was taken off-course: she was dragged off forcefully by way of Vrndāvana Forest (39). The river Yamunā was brought through the middle of Vṛndāvana, and the birds that lived on her banks followed, screeching (40).

When the river Yamunā had come across to Vrndāvana Forest, she took the form of a woman and said to Rāma (41):

"Have mercy, Rāma! This irregular deed frightens me. My water's taken the wrong shape (42), strong-armed son of Rohin̄in. By dragging me you've made me crooked in mid-river-you've made me into someone who's strayed from her own true path (43). When I've carried my diverted waters and arrived at the sea, my co-wives are bound to mock me with their foamy laughter, proud of their own speed (44). Kṛ̣na's virile older brother, take pity on me, I implore you! You're hurting me with your ploughing weapon. Resist your passion! (45). I bow my head to your two feet, Halāyudha. I want the course I was assigned. Where else am I to go, strong-armed man?" (46).

Bala watched, armed with his plough, as Yamunā, the wife of the restless ocean, made her speech. Then, tired and overcome with drunkenness, he replied (47):

"Your path is as my plough has drawn it. Refresh this whole region of ours with the gift of your waters, good-looking-for my sake (48). You've been given your instructions, illustrious river with the lovely eyebrows, so flow in peace. Move along pleasantly, and my fame will surely endure as long as the worlds endure" (49).

When they witnessed the dragging of the Yamunā, all the cattle station's inhabitants voiced their approval and bowed down before Rāma (50). But Rohin̄ī’s son dismissed the fast-flowing river and all the cattle station's inhabitants, and then 
he thought things over in his mind, came to a decision, and returned to Mathurā immediately (51). ${ }^{4}$

\section{Literature Review}

Scholarly studies of the Harivamśa, and of the character Baladeva within it, will be introduced below as required. ${ }^{5}$ But the relevant background for this scene in the secondary literature also includes studies of rivers and Indian river mythology. Almost all Indian rivers are female and are also auspicious goddesses. ${ }^{6}$ In the Mahābhārata, the goddess Gangā subsists in human form for the duration of her eight-child marriage to Śamtanu. She works on different planes simultaneously. Yamuna is not so highly characterized, but she has the same generic powers and she would have been mythologized immemorially. In the Harivamśa, Kṛ̣ṇa fancies Yamunā and Baladeva pulls her. A story about Kṛ̣ṇa marrying Yamunā appears only in later texts.

This section discusses four previous interpretations of the Harivamía 83 scene in English, with occasional explanatory tangents. These interpretations are, approximately, a mythological interpretation (André Couture), a religio-historical interpretation (Lavanya Vemsani), and two sexual-metaphorical interpretations (A. Whitney Sanford).

(1) André Couture's (2017) ${ }^{7}$ comments on the scene are brief and are a small part of a wider study. Couture stresses that both Krṣna and Baladeva are manifestations of Viṣnu (Harivamía 45.38, 56.26) and that Baladeva specifically manifests Viṣnu's aspect as Ananta-Śeșa. Śeșa is the serpent who supports the earth while the cosmos is in process (Mahäbhärata 1.32) and who, in between one cosmos and another, supports the sleeping Viṣnu in the single ocean and embodies the cosmic "remainder" (Śeșa) which will later be reactivated (Harivamśa 58.36-48, 70.1732, 90.1-4; Sharma 1986). Baladeva's role on earth, in keeping with his theological identity, is to complete and complement the actions of his brother Krṣna (Couture 2017: 240, 243, 257).

When Couture discusses the scene with Yamunā at Harivamía 83, he stresses that at this point Baladeva is separated from Kṛ̣na:

The point I want to emphasize here is that, alone in the forest, far from his brother, Samkarșana gets intoxicated and completely destabilized.... What is going on in this forest is exactly what happens at the end of the world when

\footnotetext{
4 All Harivamśa translations are adapted from Brodbeck 2019. The Sanskrit of specific verses of this passage is presented as and when they are discussed below.

${ }^{5}$ For a text-historical study of Baladeva in Mahābhārata 1-18 (but not the Harivamiśa), see Bigger 1998. For critiques of Bigger's postulated stages of textual development, see Feller 1999: 813-14; von Simson 2009: 72-73; Adluri and Bagchee 2018: 45-117. Bigger's methodology seems unlikely to have yielded reliable results.

6 On Gañgā, see Darian 1978; Eck 1996; King 2005; on Yamunā, see Haberman 2006; Kumar and James 2009; on rivers of Maharashtra, see Feldhaus 1995. For a list of male rivers, see Salomon 1984: 160.

7 First published in French in 2010-11 in Bulletin d'études indiennes 28-29: 5-49.
} 
things are inverted and the cosmic order disappears. Reminding the reader of the periodic dissolution, Samkarșana draws everything toward himself by an action contrary to the usual course of things, thereby reducing the world to the state of a remainder or śeșa. When he diverts the flow of the Yamunā from her regular course by this violent act, the peaceful Rāma is momentarily transformed into an angry deity (ugra)....The solitary Samkarșaṇa can appear on the one hand as a powerful being able to support the entire world, and on the other hand manifest himself in a sort of second state and cause a complete upheaval of the usual course of the world with his ploughshare (2017: 248).

Insofar as Kṛ̣na is not present, Couture links the Harivamiśa 83 scene with the subsequent one in which Baladeva loses his temper and kills Rukmin at a dicing match during the wedding celebrations for Kṛ̣na's grandson Aniruddha (Harivamiśa 89.17-46; Couture 2017: 249, 279-80). According to Couture, in both cases (and others) Baladeva's separation from Kṛnna results in violence that fits his deeper theological identity, since it corresponds to the pralaya, the end of the world, which marks Śeșa's change of role from supporter of the world to container of its remainder:

In other words, the transition from the figure of a powerful being entirely devoted to his svadharma (i.e. the Snake Seșa supporting the earth) to that of a Remainder during the [interval between one cosmos and another] ${ }^{8}$...takes place through a counterthrust, that is, an action made the wrong way (pratiloma, against the hair) (2017: 281).

This interpretation is commendable for its mythological depth. When applied to this scene it also seems slightly speculative and incomplete, but perhaps those are inevitable features of any interpretation. It implies that Viṣnu and Śeșa are temporarily parted during the pralaya and that Śeșa is the primary agent of the pralaya. Both of these propositions seem to be largely unsupported, not just by Couture but also by the text.

With regard to the idea that Śeșa is the primary agent of the pralaya, Couture says that Śeșa "is able to maintain the existence of the worlds as well as annihilate them at the end of a kalpa, also allowing them to revive at the beginning of another cycle" (2017: 251). Here Couture gives Śeșa a regular destructive role, whereby Śeșa does not just allow cosmic annihilation to occur, but does it himself. However, Couture does not provide supporting references. Mahābhārata 12.47.20c says that "at the time of destruction he [Nārāyaṇa] is called Saṃkarșaṇa" (kṣaye saṃkarșaṇah proktas; Fitzgerald 2004: 271), but this is not really enough to support the interpretation.

Even if one were to grant that Śeșa is the agent of the pralaya, the commonality between Baladeva in this scene and Śeșa during the pralaya is said by Couture to be

\footnotetext{
${ }^{8}$ I use the word pralaya to mean the ending of the cosmos and not the interval between one cosmos and another. For the former usage, see Monier-Williams 2005: 689, column 3; for the latter usage, see already Couture 2017: 275. Couture uses the word in both senses. Here I have paraphrased for clarity.
} 
the action of drawing everything towards oneself, ${ }^{9}$ but Baladeva only draws Yamunā towards himself. Her relocation is described in terms of disorder, but it is localized disorder, since apart from her and the creatures that live in and around her, everything else is unaffected. The analogy would require Yamunā here to represent the cosmos as a whole, but that is not a role she normally plays and nor does it correspond to any deeper mythological aspects of her identity.

Couture's interpretation here also takes Baladeva's action to be a generally destructive one, but this is at odds with its positive reception by the cowherders (Harivamśa 83.50); in fact, nothing is destroyed or absorbed. ${ }^{10}$

Thus, Couture's interpretation, although it highlights an important perspective on the character of Baladeva, is not generally convincing in terms of this scene. Other angles are necessary, to supplement it. When characters have explicit divine counterparts it can be useful to interpret their deeds in light of the identities and deeds of those counterparts, if possible; but here it is not possible to any great extent without stretching the text. And even if Baladeva does have a tendency to become unruly when separate from Krṣna, his deeper identity as Śeșa does not quite explain that tendency—not least because, as aspects of Nārāyaṇa, Śeṣa and Viṣnu are not really separate. The tendency also has to be explained in psychological terms.

(2) Lavanya Vemsani (2006: 112-28) ${ }^{11}$ interprets the Yamunā episode in terms of Baladeva's association with fertility and his role as a provider of resources. This fits with her overall historical theory that the figure of Baladeva developed out of local nāga and yakșa traditions as they were absorbed into an expanding Vaișnavism. ${ }^{12}$

Vemsani refers to Baladeva's visit to Vrndāvana as "the affectionate visit of Balarāma as an adult to Vraj to refertilize it" and says that "In the HV, the main purpose of Balarāma's return to Vraj is to pull the river Yamunā through Vraj" (2006: 124, 112). But the Harivamśa never says that moving the Yamunā (and the associated effect upon the region and its cowherders) is a purpose of the visit. Rather, the moving of the river seems to be a result of Baladeva's drunken desire to bathe (snātum icche; Harivamśa 83.28b) and of Yamunā's implicitly impolitic nonresponse to his request. Beneficial effects upon the population are retrospectively implied when the cowherders applaud Baladeva's deed, but those effects seem to be incidental to the intention behind it. According to Vemsani, "When Balarāma pulled Yamunā through Vraj animals and humans are said to rejoice on the banks of the river (HV. 83. 39-40)" (2006: 124); but I cannot find that in the text. At the end of her discussion Vemsani says that "In the HV, it is clear that the intention of Balarāma in pulling the Yamunā was to refertilize Vṛndāvan" (2006: 128). Couture has the same impression: he says Baladeva drags Yamunā "so that the

\footnotetext{
9 Couture (2017: 285-86) sees this pralaya action as the basic sense of Baladeva's name Samkarṣana. On this name, see also von Simson 2009: 75, 79-80, 82.

${ }^{10}$ Couture (2017: 236, 274, 277, 284, 291) also identifies Baladeva as pradhāna and Krṣna as puruṣa, but he does not flesh out these Sāmkhya-style identifications or anchor them in the text.

11 Vemsani 2016 is a reprint of Vemsani 2006 with minor changes (including pagination changes).

12 Compare Jaiswal 1967: 51-60; Dandekar 1975-76: 186; Schmid 2010: 253-313, 735-36. On yakșas, see Sutherland 1991; Kessler 2009.
} 
forest can be watered and fertilized again" and that Yamunā is "dragged up to that forest in order to water it" $(2017: 279,283)$. But this is not stated in the text.

As Couture $(2015: 164,168-73)^{13}$ has correctly shown, in the Harivamśa the word vraja does not refer to a specific location, but to the cowherders' settlement, wherever it happens to be. Vemsani (2006: 114) notes this too, referring to Couture. At this point in the story, the vraja is in Vrndāvana, and so when the words vraja and vrndāvana occur in Harivamiśa 83, they effectively refer to the same place, Vrndāvana being the name of the specific forest in which the vraja is located. Thus, Vemsani says that "in this story Vraj is referred to interchangeably with Vṛndāvan" (2006: 114). In the later tradition, however, Vraja is the name of the larger region in which Vrnndāvana is located (Bryant 2003: 507), and Vemsani uses the word in this sense too, which also allows the two words-both now proper nouns-to be used interchangeably when the part of Vraja being referred to is Vrndāvana.

In the Harivamśa, the first place described as vraja is the place where the cattle station was before it was moved to Vrndāvana. After a while, that former place was environmentally dilapidated and exhausted (Harivaṃśa 52.8-28), and hence Kṛ̣na emitted wolves from his body in order to provoke the cowherds to abandon it and move to Vrndāvana. Because she takes vraja as the name of a region Vraja, Vemsani manages to explain the alleged need for Baladeva's action against Yamunā (Harivamśa 83) in terms of the dilapidation of the environment at "Vraja" as described in that earlier passage (Harivamía 52), as if Baladeva's moving of the river were to refecundate that environment (Vemsani 2006: 127-28).

Sanford later takes up Vemsani's mistake and compounds it when she says that "the rendition of this story [of Balarāma moving the Yamunā] appearing in the Hindu narrative Harivamsha states that Braj had become barren since Balaram and Krishna's departure" (2012: 84). In fact, this is stated neither of Vrndāvana nor of the cattle station's previous location. That previous location had become barren before Baladeva and Krṣna left it, and it is not to there that Baladeva brings the river, but to Vrindāvana.

Vemsani's discussion of the scene thus involves some interpretive creativity. On the whole she seeks to explain the scene in terms of religious history. She speaks of "Balarāma's early cult" and "the process of his assimilation into Vaișnavism," and she takes the scene to represent concerns with fertility and sustenance that characterized that "early cult" (Vemsani 2006: 111). From this perspective, the scene is allotted an expressive or totemic function and is mobilized to serve within a story told by the scholarly literature, about the alleged development of Vaiṣnavism. That is fine in its way, even if the scholarly story is speculative and difficult to prove. But once the scene is mobilized into that expressive function, its own agenda and terms of reference are transcended and the scholarly interpretation is then not really an interpretation of the text's story. To interpret the story directly, we must focus on what it says about the past that it explicitly narrates, not what it says about the past that the scholars narrate (and would like the text implicitly to narrate on their behalf). The matter is complicated because both of these pasts include "the development of Vaișnavism" in differing ways: the text's narrated past has

$\overline{13}$ First published in French in 1982 in Journal asiatique 270: 385-400. 
Vaiṣnavism developing through Viṣnu's appearance and reception on earth as Baladeva and Kṛ̣na, and the historical past has Vaiṣnavism developing as an encompassing amalgam of local cults and figures.

Vemsani (2006: 117-19) presents a very useful chart that juxtaposes the details of the story as told in the Harivamśa with the details of the story as told in the Viṣnu Purāna, the Brahma Purāna, and the Bhāgavata Purāna. ${ }^{14}$ In the Harivamśs column of the chart, Vemsani notes that "The pulling of Yamunā is described as akin to violating a woman. This aspect is not mentioned in any other version" (2006: 118-19). Vemsani's note fits with Sanford's sexual-metaphorical interpretation, explored in detail below.

Vemsani's chart is expanded upon in her wider comparative project. In this article we are focusing just on the Harivamśa version, but nonetheless I report briefly on the Viṣnu Purāna and Bhāgavata Purāna versions here.

In the Viṣnu Purạna, the episode occurs after Kṛ̣na has disposed of Kālayavana and brought his army to Dvārakā. It is set later in time than the Harivamiśa version, and so it would have Baladeva traveling to Vṛndāvana not from Mathurā but from the much more distant Dvārakā. In Vrndāvana, the gopīs quiz Baladeva about Kṛ̣na, wondering if he has forgotten them. "So saying, the Gopís, whose minds were fixed on Krishńa, addressed Ráma in his place, calling him Dámodara and Govinda, and laughed and were merry" (Viṣnu Purāṇa 5.24.19; Wilson 1840: 570). ${ }^{15}$ Later, when Baladeva drunkenly tells Yamunā to "Come hither," he does so "not knowing what he said" (Viṣnu Purāṇa 5.25.8; Wilson 1840: 571). When she does not come, and as he is using his plough to make her, he says, "Will you not come, you jade? will you not come? Now go where you please (if you can).' Thus saying, he compelled the...river to quit its ordinary course, and follow him whithersoever he wandered through the wood" (Viṣnu Purāṇa 5.25.10-11; Wilson 1840: 572). Yamunā then appears in bodily form, but in contrast to the Harivamśa, her speech, in which she "entreated him to pardon her, and let her go" (Viṣnu Purāna 5.25.12; Wilson 1840: 572), is presented only summarily by the Viṣnu Purāna. We hear his answer: "I will drag you with my ploughshare in a thousand directions, since you contemn my prowess and strength"- - which, as far as we can tell, she has not done. He lets her go only after she has "watered all the country" (Viṣnu Purāṇa 5.25.13-14; Wilson 1840: 572). Wilson's footnote, written before any of the critical edition projects, says that "The Bhágavata and Hari Vanśa repeat this story; the latter very imperfectly.... The legend probably alludes to the construction of canals from the Jumna, for the purposes of irrigation" (1840: 572n3). After letting Yamunā go and having his bath, Baladeva is decorated by Lakșmī, spends two months there, then returns to Dvārakā and marries Revatī.

In the Bhāgavata Purāna, too, the episode occurs after the move to Dvārakā, but unlike in the Harivamiśa and Viṣnu Purāna, it also occurs after Baladeva's marriage to Revatī. The gopīs are pleased to see Baladeva, but they also weep because they

\footnotetext{
${ }^{14}$ For the Viṣnu Purāṇa version, see Wilson 1840: 569-72; for the Bhāgavata Purāṇa version, Bryant 2003: 280-83.

15 Here and below, the Sanskrit translated by Wilson may not be precisely that presented in Pathak's text. McComas Taylor's translation of the critically reconstituted Viṣnu Purāna is eagerly awaited.
} 
miss Krṣna and he left them so suddenly. Baladeva consoles them. "Bhagavān Balarāma lived there for two months_-Madhu and Mādhava-bringing pleasure to the gop̄̄s in the nights" (Bhāgavata Purāna 10.65.17; Bryant 2003: 281). One drunken night, Baladeva summons Yamunā in order to play in the water, gets offended by her lack of response, and drags her there with his plough, saying he will bring her in a hundred pieces. Her speech is quoted in two verses:

O Balarāma, O mighty-armed Balarāma, I did not understand your power. This world is supported by one fraction of you, O Lord of the universe. O Bhagavān, please release me-I am ignorant of your Lordship's transcendent nature, $\mathrm{O}$ Soul of the universe. You are compassionate towards your devotees, and I submit (to you) (Bhāgavata Purāna 10.65.26-27; Bryant 2003: 282).

Baladeva releases her, bathes, and is visited by Lakșmī. "Even today, O king, the Yamunā can be seen to flow where she was dragged, as if manifesting the infinite prowess of Balarāma" (Bhāgavata Purāṇa 10.65.31; Bryant 2003: 283).

Neither of these two Purāna versions mentions the cowherders' response to the movement of the river, as the Harivamís a version does. Both Purānas change the order of events, the Bhāgavata having Baladeva visit Vrndāvana after he has married Revatī. And as Vemsani notes, none of the Purānas describe the attack "as akin to violating a woman" (2006: 119). This fact, recorded in Vemsani's chart, provokes and justifies this article's focus on the Harivamiśa version as important on its own terms-which are thus, effectively, the terms of the sexual metaphor. Vemsani does not pursue the matter of violating a woman beyond this one remark, and her interpretation of the incident, as discussed above, is apparently unrelated to it. Yet the remark is apt. Because of how Vaiśampāyana describes Yamunā's response to Baladeva's deed in the Harivamśa, he seems to invite the human audience member-Janamejaya and Śaunaka most immediately-to think of the episode in terms of two superimposed events: a divine superhero relocating a river, and a drunken man sexually assaulting a nonconsenting woman.

How is "The pulling of Yamunā...described as akin to violating a woman" in the Harivamśa, as per Vemsani's chart? Let us explore the metaphor. After Baladeva has told Yamunā to come because he wants to bathe and after she has ignored his request, "Keeping its tip lowered, Rāma used the plough to grab the great river Yamunā by the bank and drag her, as if she were a wife straying from her duty" ( $s a$ halenānatāgreṇa tīre grhya mahānadìm I cakarṣa yamunām rāmo vyutthitām vanitām iva ॥ Harivamís 83.32$).{ }^{17}$

When he discusses this verse, Couture says that Baladeva is "bringing her back to him as a woman deviating from the rules" (2017: 247), as if Baladeva's act were to correct Yamunā's deviation, not cause it. But Yamunā is compared with a straying wife as she is being dragged by Baladeva; and according to what she herself says on the matter (see below), she would be like a straying wife insofar as she moves from her former and proper path. As she is dragged, she is described as "trembling in fear

\footnotetext{
16 At Bryant 2003: 281, verse 6 (Chapter 65), "[in turn by Kṛ̣na]" should read "[in turn by Balarāma]."

17 In the first pāda, the word after halena could be anatāgrena or ānatāgrena. The latter fits better with the word adhomukham in verse 30, but the former could specify that the plough's tip was stiff or erect.
} 
of Saṃkarṣaṇa like a woman in a state of disorder" (saṃarṣanabhayatrastā yoṣevākulatām gatā ॥ Harivaṃśa $83.34 \mathrm{~cd}$ ).

An extended allegorical description of the Yamunā as a woman was presented at Harivamśa 55.28-39 as witnessed by Kṛṇa, with different features of the river standing for different features of a woman; and the description here in Harivamśa 83 builds on that earlier description. Harivamśa 83.35-37 include aquatic analogues for Yamunā's lips, belt, tell-tale signs (cihnaih), crown, nipples, limbs, sidelong glances, discarded clothing, and tossed locks of hair. This is clearly a repertoire of erotic images. As she is dragged, Yamunā is "like a drunk woman staggering along the royal road" (matteva kuțilā nārī rājamārgena gacchatī ll Harivamísa 83.38cd).

Do as she might, her path is altered. At this point she is still a river. But then she assumes a woman's body (strīvigrahā bhūtvā; Harivamśs 83.41c) and makes a speech to Baladeva (83.42-46).

Yamuna is worried about the consequences, for her, of what Baladeva has done. She blames him for making her into a svamārgavyabhicāriṇ̄-a woman who has strayed from her own true path (Harivamśa 83.43d). The true path seems to be, at some remove, the path of marital fidelity, an interpretation that is encouraged by the earlier comparison of Yamunā with a straying wife (vyutthitām vanitām iva; Harivamís 83.32d) and by Yamunā's own reference to her co-wives (sapatnyo; 83.44b). The reference to her co-wives depends upon the common poetic characterization of all rivers as wives of the male ocean. Immediately after her speech, Vaiśampāyana confirms that Yamunā is a wife of the ocean (arnavavadhü; Harivamśa $83.47 \mathrm{c}){ }^{18}$

Pursuing the metaphor, one might note that Yamunā thinks of herself as a wife of the ocean even though nominally she does not flow all the way to the sea (ceding to Gañgā at Prayāga). ${ }^{19}$ One might also wonder whether Yamunā, this distance upstream, sees her marriage to the sea as something that obtains in the present or only in the future. The scenario she envisages with the co-wives seems to be one of competition to arrive at the ocean first, and in these terms Yamunā discernsgeographically correctly - that her new route will slow her down. To arrive first, if it makes sense to think of a river doing such a thing, could be to be one's husband's first wife, or his most favored, or most loyal. In any case, after Baladeva's intervention Yamunā is anxious for her prospects and for her status in relation to other women, and she demands that he take pity on her and restore her to the course she was previously assigned (mārgam ādiștam icchāmi; Harivamísa 83.46c).

\footnotetext{
18 Compare Harivamiśa 43.17-45, 55.39a, 59.37d, 86.35, 86.38b, 100.45; Feldhaus 1995: 43. The Bhāgavata Purāna (10.58.13-29) has an episode in which the Yamunā becomes Krṣna's wife, but this is not in the Harivamís. The Harivamśa mentions Kālindī Mitravindā as one of Kṛ̣na’s wives (88.41, 93.48, 98.4, 98.13), who lives in a palace in Dvārakā and so is apparently not Yamunā. This could be Yamunā by the name Kālindī only if Kālindī and Mitravindā were different wives; but then the stated count of eight main wives of Krșṇa would be breached and Mitravindā would want some of Jāmbavatī’s listed children. Regardless of the Bhāgavata Purāṇa story, the Harivamiśa seems to understand Kālindī Mitravindā as one woman.

19 Haberman notes that "many devotees of the Yamuna continue to regard the combined rivers as the Yamuna" (2006: 170), and he also refers to a tradition whereby after the confluence the two rivers flow side by side (256-57n88); but these seem to be minority opinions.
} 
Pursuing the metaphor leads to strange considerations, due to the limits of, and interference between, different aspects of the metaphor of a moved river as a wife violated, forced into infidelity, and compromised as a result. The reductio suggests from one perspective that it is a metaphor and that what really happens here is that Baladeva moves a river. But nonetheless the metaphor is embodied as more than just a metaphor, since Yamunā takes form as a woman and speaks.

The interpretations of Couture and Vemsani prioritize the nonsexual event that is most straightforwardly on the surface of the text and underplay the sexual event that metaphorically accompanies it. However, for the individual male or female audience member, with their own sexual history and experience, the metaphorical accompaniment may have a special existential charge.

This metaphor is particularly complex because of the mythology of Indian rivers and their relations with men. Gangā, for example, is the ocean's chief wife (Harivamśa 43.15-45), but she is also maritally linked to the great gods Viṣnu and Śiva (Eck 1996: 146-47, 150; King 2005: 167) as well as temporarily to King Śạtanu. The link between Gangā and Śiva is also generalized into a trope whereby Siva represents the mountain at a river's source. Anne Feldhaus says that "the relationship between Śiva and rivers has a sexual element to it. But the imagery is not as explicitly or directly sexual as some might expect" (1995: 26). Feldhaus (1995: 53) also notes that the rivers of Maharashtra are all referred to by the term suvāsin $\bar{l}$, which usually denotes a woman in the auspicious phase of life, with a living husband. But Feldhaus characterizes the ocean as a merely "theoretical" husband:

The overwhelming evidence is that the rivers, and the goddesses of rivers, are considered suvāsinīs even though there is hardly ever any particular husband figure with whom they are connected. In this they are like female temple dancers (devadāsis) or prostitutes, or like the heavenly counterpart of such human females, the apsaras. None of these beings can be widowed, because none of them is married to a mortal. Hence, all of them are extremely "auspicious"- they stand, that is, for beauty, sexuality, prosperity, plenty, and other good things of life in this world.... The model for all the other sorts of river divinities, as well as for the femininity of the rivers themselves, is the apsaras, the heavenly nymph whose beauty and sexuality make her the natural opponent of the ascetic (1995: 58).

At the time of the Harivamśa, Yamunā seems to fit this pattern: her marital or amorous link to Kṛ̣na is a later development (Haberman 2006: 110-20; Kumar and James 2009: 819). But she clearly identifies herself as the ocean's wife. However, although her response to Baladeva's deed is expressed in terms of her marriage, the more immediate narrative issues are obedience and consent.

Yamunā's birth as Yam̄i is described in Harivamśa 8, in connection with the solar lineage. Her parents were Vivasvat (the sun) and Samjñ̃ā, and she had an elder brother, Manu, and a twin brother, Yama (Harivamśa 8.6-7). It is said that "the glorious girl Yamī...became the supreme river Yamunā, the weal of the world" (yamī kanyā yaśasvin̄̄ | abhavat sā saricchreșthā yamunā lokabhāvan̄̄ \| Harivamiśa $8.46 \mathrm{bcd}$ ). Yamunā's family background as presented here recalls $\operatorname{Rg}$ Veda 10.10, in 
which Yamī proposes that her twin brother Yama have sex with her and he argues against this (Kulikov 2017). That Yamī's proposal is congruent with her own sexual desire is clear from Rg Veda 10.10.7 and 10.10.11; and Stephanie W. Jamison and Joel P. Brereton (2017: 1382) suggest, referring to $R g$ Veda 10.13.4, that Yama did eventually comply. In the $R g$ Veda (10.10.4) the parents of Yama and Yamī are a gandharva and a water nymph, not Vivasvat and Samjñ̄ā; but the Yama and Yamī in the Harivamśa are apparently intended to be the Yama and Yami known in the $R g$ Veda. Nonetheless, the Harivamśa does not have to stress Yamunā's identity as Yama's twin sister Yamī, since it also knows Yamunā as Kālindī, the daughter of Mount Kalinda down whose slopes she first flows (Harivamía 52.26-27). ${ }^{20}$ The existence of two different Yamunā origin myths fits Duryodhana's statement that "The origins of heroes and rivers are obscure" (śürāṇām ca nadīnām ca prabhavā durvidāh kila \|l Mahābhārata 1.127.11cd).

Baladeva's Māhātmya ("Praise-Song") mentions the Yamunā incident:

The great river was heading for the salty sea

crowned with waves and surges of swift water

when Yama's sister Yamunā was dragged by the plough

and fetched to face the town.

lavaṇajalagamā mahānad̄̄

drutajalavegataramgamālin̄̄ ।

nagaram abhimukhā yad āhrtā

halavidhṛtā yamunā yamasvasā $\|$ Harivamísa $90.17 \|^{21}$

This is the only mention of the incident after Harivamśa 83. This description of Yamunā as Yama's sister matches the identification of Yamī and Yamunā in Harivamśa 8. As in Harivamśa 8, it evokes her Vedic sexual history; and here it does so explicitly in connection with the Baladeva incident. This provides support for the sexual-metaphorical interpretation. Perhaps Vaiśampāyana's subtext is that Yamunā's sexual history is relevant to this interpretation and would tend to reduce the perceived gravity of Baladeva's offense. ${ }^{22}$

(3) Two sources by A. Whitney Sanford are discussed in this article (Sanford $2000,2012)$. In the earlier of those two sources, Sanford does not discuss the Harivamía as such; her particular concern is the mythology of the two brothers Baladeva and Krṣna as it plays out in the lyrics of the sixteenth-century poet-singer Paramānanda. That is perhaps more than a thousand years later than the Harivamśa account. Nonetheless, the interpretation in Sanford 2000 is applicable to the Harivamśa account, in particular Sanford's identification of Baladeva's act as, at some level of connotation (as described above), a sexual attack. I quote several passages:

\footnotetext{
${ }^{20}$ See also Mahābhārata 1.90.28, 2.9.18, 4.5.1.

21 This is one of only twenty-six non-anuștubh verses in the critically reconstituted Harivamśa, thirteen of which occur in a block at the very end of the text.

22 In recent times, legal opinion has been divided on the question of whether, and under what circumstances, the alleged victim's sexual history should be admissible as evidence in rape cases. See Heenan 2003; Levanon 2012; McGlynn 2017.
} 
With his plough, he [Balarāma] forcefully relocates the river Yamuna, an act which appears somewhat antithetical to pastoral representations of Braj. (Though such terms might automatically invoke Freud, they do not necessitate a Freudian analysis.)

Contrasting Balarāma and Kṛ̣ṇa's sexuality bears out this point: Although critics have called Krṣna wanton in reference to his erotic dalliances with the gopīs, Kṛ̣na's sexuality fits into the pastoral mode; references to his sexuality are always nuanced and discreet, veiled in the guise of rasa and aesthetics. As the exemplar of the cultivated rustic, Kṛnna reveals the softer edges of the refined rustic, while aspects of Balarāma illustrate the "unconstructed" rustic. Balarāma's love of wine and lust, for example, deviate from the pastoral, the urbane rasika, and represent those qualities which are less urbane and less benign. In Balarāma lurks those dangerous qualities and urges which are not constructed and sanitized by the Braj pastoral mood.

Balarāma as a Nāga represents uncontrolled and aggressive urges.

Balarāma's act [against the Yamunā] has obvious connotations of rape, ${ }^{23}$ and the plough represents a penis, both linguistically and thematically.

The implied hierarchy between the illustrations of Balarāma and Kṛ̣na's sexuality fosters the superiority of Krṣna's devotion to his bhaktas over Balarāma's anti-social qualities (Sanford 2000: 367, 373, 379, 382, 385).

Sanford's remarks are made in view of a contrast between Kṛ̣na's sexual experience and Baladeva's. The sexual-metaphorical interpretation that Sanford proposes here fits Vemsani's chart and will be explored further below, beginning after the literary review with a closer look at the story of the two brothers Baladeva and Krṣna as presented in the Harivamiśa before this scene.

(4) The second source by Sanford discussed here is her book Growing Stories from India (2012), which mobilizes ethnographic work in Baldeo just east of the Yamunā — the land Baladeva today protects as its lord—into a critique of industrial farming narratives and practices. In Baldeo, Baladeva is revered as a provider of agricultural fertility, along the lines sketched above when discussing Vemsani's interpretation. In this mythology, Baladeva's deed against the Yamunā is his commandeering the fertility of the earth for the benefit of the community he dutifully protects. His deed subordinates the providing female other.

In this respect, Baladeva repeats the founding deed performed in the Harivamisa by the first king, Pṛthu Vainya, against the earth. ${ }^{24}$ Prthu's scene is as horrific as Baladeva's. Prthu, seeking economic security for his subjects, takes up his bow and

\footnotetext{
${ }^{23}$ Regardless of specific usages and legal definitions of the word "rape" in twenty-first-century discourse, the concept is transferable to ancient India. In the Rāmāyana, Sìtā withholds her sexual consent from Rāvana, and he cannot rape her due to a curse, cast upon him after he previously raped Rambhā, that his head will shatter if he ever does such a thing again (Rämāyana 7.26; Mahäbhārata 3.264.58-59). See also Harivamśa 91.7-8 for a similarly negative portrayal of Naraka's rape of Kaśeru.

${ }^{24}$ Sanford $(2012: 63,94-95,111,120)$ discusses the story of Pṛthu in connection with Baladeva's action against Yamunā. (On page 94 Sanford refers also to the work of Herman [1979].) On the story of Pṛthu, see also Fitzgerald 2004: 131-35; Brodbeck 2016: 400-406.
} 
arrows against the earth, who runs away across the worlds in the form of a cow to no avail and has to beg for her life against the terrorist male. In the process, she reminds him that he depends upon her and that women may not be killed, and promises him bounty if he treats her right (Harivamśa 5.42-52). A productive partnership is then agreed, and Prthu initiates ploughing and grain agriculture (Harivamśa 6.11-15). But from one perspective, his is a disrespectful, exploitative attack: he demeans and corrupts the earth-whose proper bounty would have been forthcoming anyway-and corrupts himself in his own elevation.

If we try to relate the agricultural role that Baladeva plays in the mythology of Baldeo (as researched by Sanford) to the Harivamśa, that agricultural role seems to be played by Prthu in this text, not by Baladeva. As Georg von Simson says, "early texts like the MBh, HV or Kautalìya-Arthaśastra do not associate Balarāma with agriculture" (2009: 79n59). In the Harivamśa, after Baladeva has moved the river the cowherders praise him for it, but there is no suggestion that they are about to abandon cowherding and take up plough agriculture. Presumably it just means they and their cattle will not have so far to walk to the river. This is an important point. In the context, apart from his use of the plough and the resonances from the Prthu story, there is nothing to mark Baladeva's action as agricultural. Robert P. Goldman says that "Balarāma with his plough seems somehow an anomalous figure among the Vrajas who, at least according to a verse in the $H V$ (52.18), do not practice cultivation" (1980: 177n10). Couture says:

The assumption that Krṣna's elder brother might be an ancient agricultural deity more or less well integrated to Hinduism dates back to the nineteenth century only, an issue that merits more attention....Christian Lassen...already considers Samkarṣana as an agricultural deity, especially on account of the ploughshare and the pestle associated with him. ${ }^{25}$

It is not the Indians, but the first Western mythologists who connected the name of Samkarșana with ploughing $(k r s s i)$ and rapidly transformed the hero into an agricultural deity (2017: 219, 285).

As Couture says, the issue merits more attention.

Sanford emphasizes the gendered mythological overlap between Baladeva versus Yamunā and man versus nature. ${ }^{26}$ In terms of man versus nature, plough agriculture is a more violent and intrusive type of land use than any combination of grazing, browsing, gathering, and basic horticulture. As the dharmic butcher said to the brahmin:

\footnotetext{
25 See Lassen 1867: 766-68. Couture (2017: 285) also quotes Langlois (1834: 262n7), writing to similar effect.

26 On man versus nature, with emergent explanation of how and why the gender-specific word "man" is appropriate here, see Griffin 1978; Merchant 1989.
} 
They hold that plowing is good, but it is well enough known what injuries it inflicts. Men who furrow with plowshares kill many creatures that lie in the ground, as well as plenty of other living things, what do you think? (Mahābhārata 3.199.19; van Buitenen 1975: 624). ${ }^{27}$

Sanford says that "when the earth and the female body are viewed as property and resources to be exploited, they become commodified and viewed solely in terms of production or the capacity to fill others' needs"; thus Baladeva's deed "normalized patterns of entitlement to the earth's - and women's - fertility and productivity that are enacted in multiple agricultural and social scenarios" (2012: 59, 81). In its mythology of kingship, the Mahäbhärata makes it clear that the protective role involves violence and control; and if that role is extended to Baladeva, it seems obvious to interpret his deed against Yamunā as a reprise of Pṛthu's actions against the earth. For Sanford (2012: 116, 194-224) it is then possible, particularly in view of how polluted the Yamunā has now become, to view the narrative as a kind of tragedy and to use it as a prompt for developing a new agricultural narrative of reciprocity and citizenship rather than domination.

Baladeva's use of the plough, to which we will return in due course below, invites such an association even if the Harivamśa narrative does not build on it. But in view of the differences between Baladeva in the present-day mythology of Baldeo and Baladeva in the Harivamśa, if we seek to interpret Baladeva's deed against Yamunā in Harivamśa 83, then Sanford's discussion in Growing Stories, for all its undoubted importance, seems out of range. Its focus on agriculture is largely beside the point of Baladeva's deed in the Harivamisa, and its application to the female body is also not a neat fit, since Yamunā, as the wife of another, is not in any special relationship with Baladeva (as the earth would be with the king). If the plough is to signify here not with its otherwise obvious agricultural connotations, and not in terms of the dharmic operations within a marriage, and not even as a weapon used in combat against an armed other, then its interpretive range seems to be very limited.

To sum up this long section. Couture has suggested a mythological interpretation of the Harivamśa scene, and Vemsani a religio-historical interpretation. Sanford has suggested two sexual-metaphorical interpretations, neither of them based on the Harivamís scene: the first is based on Paramānanda's lyrics and contrasts Baladeva and Krṣna, and the second is based on recent fieldwork and pairs Baladeva with the earth. The rest of this article expands upon Sanford's first sexual-metaphorical interpretation with reference to the Harivamśa. The following section explores Sanford's suggested contrast between Baladeva and Kṛṣna in terms of the Harivamśa data, and then, using that data as context, the section after that fleshes out the interpretation by reviewing the scene and highlighting certain details.

$\overline{27}$ Couture (2017: 288) also quotes this verse. See also Manusmrti 10.83-84; Bowles 2018: 249-50. 


\section{Kṛ̣na and Baladeva}

Before considering Baladeva's sibling relations in the Harivamśa, it is worth mentioning his prenatal experience-for that is for Baladeva, as it is for us all, the basis upon which postnatal experience builds (Cendrars 1972: 120). Devakī became pregnant by her husband Vasudeva in Mathurā, and that unborn child was Baladeva. In the seventh month, Viṣnu's female companion, the goddess Nidrā (Sleep), extracted Baladeva from Devakî̀s womb and inserted him into the womb of Vasudeva's other wife Rohin̄ī (Harivamiśa 47.30-31, 48.2-7), who then gave birth to him in the cattle station (49.1) and raised him as her own, as Rauhineya. The violence enacted upon the unborn Baladeva (and his mothers), which in the Harivamśa $(47.31,48.6)$ is the reason for his name Samkarsana the Extraction, could prefigure his violence upon the Yamunā. He was violently displaced, and he violently displaces. In view of this similarity, perhaps it is significant that the transferral of Baladeva from one womb to another was effected by a female. Although Nidrā and Yamunā are different characters, the two attacks could be interpretively related. ${ }^{28}$

On to Krṣna and Baladeva. Before the Yamunā scene, these two have been great childhood companions and have often acted together, but Krṣna, the younger of the two, has performed more miraculous deeds than Baladeva and has received more praise and attention as a result. This fits with their divine identities, since Kṛ̣na is Viṣnu-Nārāyaṇa and Baladeva is merely his aspect as Śeșa. But both are now human. Baladeva seems to be less continuously aware of his divinity than Kṛ̣na is: at Harivamśs 58.35-49 Kṛ̣na reminds Baladeva of his divinity, which he has seemingly forgotten (aho 'yam mānușo bhāvo vyaktam evānugṛhyate I 58.35ab). So Baladeva is no doubt subject to human emotions and responses, and accordingly he might feel slightly overshadowed and overstepped by his younger brother.

Before Kṛṣna and Baladeva were taken to Mathurā for the bow festival, Kṛ̣ṇa's first sexual experiences were narrated, but Baladeva's were not. Harivamís 63 describes how Kṛ̣na enjoyed himself, but it does not mention Baladeva:

Gorgeous women pressed their breasts against him with nipples erect, and gazed at him from faces with fluttering eyes. Though their fathers, brothers, and mothers told them not to, the cowherder women pursued Krṣna at night, bent on pleasure.... Their bodies smeared with dung and dust, they surrounded Krṣṇa, delighting him as cow elephants in heat delight a bull elephant. Some women, doe-eyed, unsated, drank Krṣna in with eyes bright with love, smiles on their faces. Other cowgirls, still thirsty after gazing upon his face, found another kind of pleasure in the night and, lost in passion, drank him in. When Dāmodara cried out those gorgeous women were thrilled, and they seized upon the sounds he made and the words he willingly spoke. The hair of the cowherd women was parted and plaited, but disordered by their passionate thoughts, it came loose and fell beautifully onto their nipples. And that's how

\footnotetext{
${ }^{28}$ Narrative symmetry between cause and effect is often seen in the Mahäbhärata, albeit the words "cause" and "effect" are too strong. See the examples discussed in Mehendale 1984 (compare Goldman 1978: 337, 376n95): Pāṇụu at Mahābhārata 1.109, etc.
} 
Krșna, adorned by a ring of cowgirls, enjoyed himself with pleasure in the moonlit autumn nights (63.23-24, 63.30-35).

Much of the language in the Krṣna scene is ambiguous, but there seems to be a clear contrast between the cowgirls who drank Krșna just with their eyes and the cowgirls who were not satisfied with that and also drank him some other way. In the Harivamía there is no suggestion that Krṣna's sexual activity should be interpreted as a theological metaphor: in this scene he acts as a human with other humans (Coleman 2010: 387-92). ${ }^{29}$

The following chapter, Harivamśa 64, which describes Kṛ̣na's killing of the demon bull Arișta, directs our interpretation of Kṛṣna's sex scene. Its description of Arișta's molestation of the cows mentions Arișta's sexual behavior: as well as being violent and unruly, he was "swift in mounting cows" (gavāroheșu capalas; Harivamśa 64.6a). "The wild bull went around making the cows miscarry their calves. On he went, swiftly helping himself to the heifers" (pätayāno gavām garbhān drpto gacchaty anārtavam I bhajamānaś ca capalo gṛștīh sampracacāra ha II Harivamís 64.8). ${ }^{30}$ The adverb anārtavam ("unseasonably") could do double duty in this verse, implying that pregnant cows miscarried and/or that Arisța helped himself to cows not in season. In any case, the violence that precipitates Arisța's death clearly includes the violence of unwanted sexual activity. The word capala occurs twice, implying that Arișta was so swift that the heifers could not evade him. These bestial details, for which he was killed, contrast with the human sexual activity in the previous chapter, underlining the fact that Krṣna's sexual partners welcomed and enjoyed his attentions.

Harivamśa 63 and 64 thus depict the contrast between consenting and nonconsenting female sexual partners (Matchett 2001: 53). So when Baladeva's forest party is described twenty chapters later in Harivamśa 83, it has been set up as a doublet with Krșna's sex scene.

Manusmrti 4.184 says that a male's older brother is equivalent to his father. ${ }^{31}$ Perhaps this is among the things that Baladeva learned only in his orthodox education under Sāmoīpani (Harivamśa 79). Goldman (1978: 328, 1980) has discussed deference to the elder brother in his Oedipal studies of Mahäbhārata and Rāmāyaña stories. ${ }^{32}$ Goldman (1978: 343) quotes G. Morris Carstairs who says that "younger brothers are required to enact a symbolic self-castration" (1957: 160).

Alf Hiltebeitel has called attention to the idea of an older brother being overstepped (ati-kram) by a younger brother in the Mahābhärata, in the case of Yudhișthira Pāṇ̣ava and his younger brothers Bhīma and Arjuna. Bhīma briefly

\footnotetext{
29 In Sanford's later account, "While Krishna and the gopis danced under the moonlight, Balaram hid behind a rock and watched" (2012: 79). Perhaps this detail originated in one of the many oral traditions. It is not in the Bhägavata Purāna as Sanford's note suggests (compare also Sanford 2005: 110n16).

${ }^{30}$ In the Harivamśa edition, the last syllable of the word anārtavam has a wavy line underneath it, which indicates that the two recensions differ and that the northern version has been prioritized. Manuscripts Ś 1 , K3, Ds, D4.6, T2, G2-4, and M1.3.4 (that is, a few northern manuscripts as well as most of the southern ones) read anārtavat, meaning something like "without a qualm."

31 See also Manusmrti 9.57-58, 9.108.

32 Compare Fitzgerald 2007: 194-204.
} 
wants to burn Yudhișthira's arms in protest at his behavior during the dicing match, but Arjuna warns him against overstepping Yudhișțira (Mahābhārata 2.61.1-9; Hiltebeitel 2001: 241, 248). Arjuna himself has overstepped previously, by interrupting when Yudhișțira and Draupadī were alone together (Mahābhārata 1.204-205; Hiltebeitel 2001: 264-67; Brodbeck 2009: 182-86). This idea of overstepping is central to the Mahābhärata, where the rājasūya ritual and the Kurukșetra war involve Pāndu's junior branch asserting itself over and above Dhṛtarāșțra's senior branch (Brodbeck 2012) and where Arjuna's junior branch also then prevails over Yudhișthira's senior branch.

The examples that Hiltebeitel uses show that this idea of overstepping rests on a specific kind of masculine paradigm and that the authority of the elder brother over his brothers is, among other things, a sexual kind of authority. The elder brother is supposed to marry before his younger brothers, who then follow in sequence (Mahābhārata 1.182.8-9; Manusmrti 3.154, 3.170-172, 11.61). This is one of the reasons why Draupadī, won by Arjuna, must also marry Arjuna's elder brothers before she marries him (Mahābhārata 1.187.18-25). As Yudhișțira says to her father Drupada when explaining the polyandric proposal: "I am still unmarried and so is Bhīmasena Pāṇụava" (aham cāpy anivișto vai bhīmasenaś ca pāṇdavaḥ I Mahābhārata 1.187.23ab; van Buitenen 1973: 367). The principle is clear, though here Yudhișthira does not mention that Bhīma has already had a temporary marriage with Hiḍimbā (Mahābhārata 1.143), which thus fits with Bhīma's later outburst at the dicing match. In the Mahābhārata's presentation of Arjuna interrupting Yudhișthira and Draupadī alone together (1.204-205), the sexual ordering aspect is emphasized by the specific verb anu-pra-viś, "enter after," which Hiltebeitel notes "is used six times in this episode... and nowhere else in this sense" (2001: 266n69).

The purpose of our brief focus here upon the Pāndava brothers is to exemplify the Mahābhärata's discourse about the eldest brother's precedence in sexual matters and in other matters described using sexual metaphors. This discourse must also apply to the brothers Vāsudeva, where Baladeva seems to have been overstepped by Krṣna. ${ }^{33}$ Von Simson says of Kṛṣna that "Though being the younger brother, and against Indian family tradition, he overshadows his elder brother completely" (2009: 84). This seems to be a necessity on the theological level, because with Ananta-Seșa and Viṣnu, Viṣnu has to be the main man. The story might conceivably have had

\footnotetext{
33 For ati-kram, vy-ati-kram, and sam-ati-kram in the Harivamśa, see 5.4, 5.8 (Vena transgresses against Veda, dharma, and maryādā); 7.36 (a Manu period elapses); 10.17 (Triśanku transgresses against his father and his guru); 13.31, 13.38 (Acchodā transgresses by wishing Vasu was her father); 38.14 (Kālanemi says Viṣnu has outstayed his time); 43.20 (the ocean transgresses its shore); 48.39 (Kamsa was unable to transgress the will of the gods); 73.27 (the sexual transgressions of women); 75.18 (Krșna will not transgress the rules of combat); 83.41 (Yamunā came across to Vṛndāvana); 91.45 (Kṛ̣na crosses rocky mountains); 92.46, 92.48 (Krș̣na astride Garuḍa goes beyond the range of the sun and moon and passes over the residences of the gods); 96.9 (Krṣna and Baladeva cross the room to greet Rohinī); 96.66 (Kṛṣna crosses mountains); 99.13 (in lusting after Pradyumna, Māyāvatī violates morality); 103.1, 103.13 (Arjuna and Krṣna cross mountains, rivers, lakes, and Mount Gandhamādana); 107.33 (Ușā's transgression, in the form of an erotic dream, is not sinful); 108.13 (Ușā transgresses by having premarital sex with Aniruddha); and 118.31 (Indra has sex with Janamejaya's wife). Though none of these usages describe a violation of the precedence of the elder brother, many contain the idea of violating proper hierarchy and a sexual component is clear in some of them.
} 
Krṣna born before Baladeva, but it does not; ${ }^{34}$ and thus, on the human level, it involves, in Baladeva, the psychological aspects of being overstepped.

Goldman (1978: 350, 362) understands Krșna's dealings with Kamsa in terms of Kṛ̣na being something like "the western oedipal hero" in his rebellion against his father-figure Kamsa. This seems hasty, since Kṛ̣na's father-figures in this regard are rather his actual father Vasudeva and Kamsa's father Ugrasena. Kṛ̣na killed Kạ̣sa in order to liberate those two father-figures from the abuse and persecution of a demonic upstart son (Ugrasena's son Kamsa), who should have respected them but did not. But nonetheless, Krṣna's activity here is not led by his elder brother. Regarding Kṛṣna and Baladeva, Goldman says:

Kṛ̣na...is... a member of a fraternal pair that shows signs of functioning as a composite hero.... Balarāma, although he is Kṛ̣na's elder brother, is unquestionably his subordinate in status and power, and in the affections of the poets, theologians and devotees. Yet, despite Balarāma's obscurity and his relegation to a somewhat secondary role in the account of Krṣna's career, it appears that whatever role he has in these accounts is not so much supplemental as complementary to that of Kṛ̣na.... Certain of Balarāma's characteristics are notably different from and even diametrically opposed to those of Krṣna and may, perhaps, as in the case of the Pạndavas serve to establish a more fully rounded composite hero (1980: 151).

Goldman (1980: 167-70) discusses in particular the Dāsaratha brothers, where Lakșmana seems to suppress his own sexuality as part of his younger-brother role towards Rāma. This is not the kind of treatment that Baladeva gets from Kṛnna.

This section has discussed Harivamśa chapters 63 and 64. It has proposed that Krṣna sexually oversteps Baladeva's senior privilege and that the immediately following Arișta scene is a tool for the interpretation of Baladeva's sexual scene to come.

\section{Return to the Passage}

This section reviews the passage in light of the opening provided by Sanford 2000 and in light of the wider Harivamiśa data presented above.

By the time Baladeva returns to Vrndāvana, he has graduated and seen active service. The cowherders have heard about all his exploits since they last saw him (Harivamśa 83.11-13), and they receive him with honor, touched by his visit. Baladeva lauds the bond between them and himself based on his having grown up among them (Harivamśa 83.15-17), and in the course of his speech "the faces of the cowherd women lit up with pleasure" (saṃhrștavadanās tatra babhūvur gopayoșitah | $83.18 \mathrm{~cd})$.

\footnotetext{
34 Couture (2017: 273) notes that this means a kind of "inversion" and links it to the "inversion" that takes place during the pralaya; von Simson (2009: 84) links it to Baladeva's representing the crescent of the waning moon, which must appear before the black moon represented by Kṛ̣na.
} 
Then Baladeva goes into the forest and enjoys himself (tato vanāntaragato reme rāmo mahābalah ॥ Harivamśa 83.18ef). The cowherds, who "know the right time and place" (deśakālajñair), bring "the guardian goddess alcohol" (gopā...vārun̄ī; Harivamśa 83.19). Baladeva gets drunk and delights in delectable flowers, foods, and fruits (Harivamía 83.20-22). He reclines in pleasure, with his plough and his club (Harivamísa 83.23-27), drunk (matta; 83.27a, 83.28a). ${ }^{35}$

Then he hails Yamunā and tells her to come right up to him, because he wants to bathe. He uses the vocatives mahānadi, "great river," and sāgaramgame, "flowing to the sea" (sa matto yamunām āha snātum icche mahānadi I ihaiva mābhigacchasva rūpiṇi sāgaramgame ॥ Harivamiśa 83.28). ${ }^{36}$ Yamunā sees that he is drunk and ignores his request (saṃkarșaṇasya mattoktām bhāratīm paribhūya sā I nābhyavartata tam deśam; Harivamśa 83.29abc). In doing so, she is said to be "misguided by her feminine nature" (strīsvabhāvena mohitā; Harivaṃśa 83.29d). This detail is significant, and we will return to it below. Baladeva's reaction is to lower his plough for dragging (cakāra ca halam haste karșaṇādhomukham balī ॥ Harivamiśa $83.30 \mathrm{~cd})$.

There is the detail here about the lotus garlands: "Lotus garlands tumbled onto the drinking ground and released their own special pollen-colored fluid from their blossom stores" (tasyām tu pānamedinyām petus tāmarasasrajạ̣ I muтucuh pușpakośaiś ca svam rajorañjitam jalam \|l Harivaṃśa 83.31). Earlier, the cowherds brought Baladeva "masses of lotus blossom, freshly lifted and picked" (sadyoddhṛtāvamuktam ca prabhūtam kamalotpalam \| Harivamísa 83.22cd). The fall of the lotus-blossom garlands seems to result from Baladeva rearranging himself so as to face Yamunā with his tool grasped. In particular overtones, the garlands might also be young women or clothes.

The "drinking ground" (pānamedin̄i) onto or into which the garlands fall could potentially be a place where the river can be easily accessed by thirsty cattle, rather than or as well as the place where Baladeva is drinking alcohol. If this were the case, then the garlands would be falling into the river, which would help us to make sense of the word jalam: the water would be colored by the pollen (rajorañitam). This image is significant because the coloring of river water happens by standard during the monsoon and is understood as the river's menstruation by analogy with the menstruation of a human woman (Feldhaus 1995: 46; Kane 1974: 660-61). In both cases, the coloring is a marker of renewed fertility, albeit on an annual rather than a monthly cycle in the case of the river. However, Richard Salomon dates this idea to a period later than the Harivamśa:

The pollution of rivers during the rainy season noted in earlier Sanskrit texts referred only to the earth carried off by the fast-flowing currents: that is, rajas in the sense of "mud". Later on, apparently in medieval times, this physical impurity came to be symbolically associated with a seasonal "menstrual flow"

\footnotetext{
35 Elsewhere in the Harivamśa the uncompounded word matta describes male elephants in the condition of musth (62.2b, 74.22-23, 81.24b, 82.12c, 84.16c, 84.18b, 96.58a, 107.60b), for example, and male animals and birds showing would-be mating behaviors (59.39a, 59.45d, 62.50ab, 93.65a, 94.5a).

36 Rupin̄i, "beautiful," is in the nominative case, though it can be translated as another vocative; either way, it is Baladeva referring to Yamunā.
} 
of the female rivers, and rules were formulated to prohibit bathing in these "menstruous" (rajasvalā) rivers, just as intercourse with a menstruous woman (rajasvalā) is prohibited (1984: 173).

Salomon's chronological conclusion would discourage us from understanding rajorañjitam in terms of Yamunā's cyclical menstruation. A more obvious understanding might be in terms of Yamunā's generally dark hue, particularly in comparison with that of the Gangā, as evident at their confluence (Haberman 2006: 12, 93, 111; Kumar and James 2009: 819). In this sense, the fall of Baladeva's garlands into the water could serve as an origin myth for the Yamunā's color. But the general problem with these interpretations, based as they are upon the "drinking ground" being part of the river, is that, according to the Harivamśa account, it was only after his garlands had fallen that "Keeping its tip lowered, Rāma used the plough to grab the great river Yamunā by the bank and drag her" (83.32). When the garlands fell, the Yamunā, though apparently within earshot and within the reach of his plough, was still far enough away for Baladeva to want her to come closer.

Baladeva's use of the plough to drag Yamunā calls for further comment. The plough weapon descends upon Baladeva in the battle against King Jarāsaṃdha, two chapters before his visit to Vrnndāvana. Baladeva is once referred to by Vaiśampāyana as Halāyudha, "the one with the plough as his weapon," even before the battle against Jarāsaṃdha, while Baladeva and Kṛ̣na are fighting against Kaṃsa's elephant Kuvalayāpị̣̄a; this reference seems to be anachronistic (Harivamśa 74.36). When the plough descends in the battle against Jarāsamdha it is called Samvartaka, and it descends along with Baladeva's club Saunanda and Kṛṣna's bow Śārnga and mace Kaumodakī (Harivamísa 81.55-64). ${ }^{37}$ These weapons help the Yādava-Vṛ̣nis to keep Jarāsaṃdha at bay. Before that, Akrūra saw the plough and the club with the snake Śeșa beneath the waters of the Yamunā while taking Krṣna and Baladeva to Mathurā (Harivamśsa 70.17). In the Harivamśa, Baladeva is called Lāngali, Lāngalin, Halin, and Haladhara, "he who has (or carries) a plough," and also Halāyudha, "he who has a plough for a weapon." He is well endowed, and the plough is his special weapon. But he is only an aspect of the greater Viṣnu-Nārāyaṇa, who thus has that weapon too. When Viṣnu goes into battle against the asuras in the Tārakāmaya war, he has a "sticking-up plough" (halodagra; Harivamiśa 32.25a) in his armory, and when Kṛ̣ṇa goes into battle against Naraka without Baladeva, Naraka's Dānavas are "smashed up by his great plough" (mahālāingalanirbhinnāh; 91.48a).

The plough needs no introduction as a tool for the human taming of land. It is a metallic weapon against the wilderness. The agricultural connotation is there in the name of Baladeva's weapon. In the $R g V e d a$, the blissful and threatening female forest (or wilderness) is said to be "unploughed but full of food" (bahvannàm akrṣivalām; 10.146.6b; Brodbeck 2017: 20). One might see the forest here as an

\footnotetext{
37 According to Couture (2017: 244-45), Rāma took the plough Samvartaka and the mace (gadā) Kaumodakī and Kṛ̣na took the bow Śārnga and the club (musala) Saunanda; but I do not think that is right.
} 
unmarried and thus dangerous goddess, ${ }^{38}$ parthenogenetically reproducing a potentially strange fruit. From the patriarchal and Brāhmanical point of view, the threat of the forest is to be tamed, so the forest's threatening aspect is represented as a desire that is then consummated by the plough. The forested land is female, the hypothetical plough-person implicitly male, and the hypothetical ploughing would be their lawful sexual intercourse. A man's wife is his field, and as marital duty he iteratively ploughs that field and scatters his seed into it at the appropriate point in its cycle (Manusmrti 9.32-56, 9.145, 10.69-72), and what was once forest thus becomes more legitimately full of food, and full of more food. ${ }^{39}$ The femininity of the forest, and more generally the femininity of the earth, ${ }^{40}$ sets up the analogy such that the plough optionally connotes the phallus. Jan Gonda observes that "In Sanskrit, the word längala- designates the plough as well as the penis" (1993: 133). ${ }^{41}$

If and when Baladeva uses the plough against a woman, it seems natural to consider interpreting the plough as his phallus. In the Harivamśa, Baladeva uses his plough in battle against men repeatedly, ${ }^{42}$ but the incident with Yamunā is its only narrated use against a woman. ${ }^{43}$ When Baladeva threatens the town of Hāstinapura with his plough at Harivamśa 90.8-15, no feminine words are used to describe the town (nagara, pura).

To return again to the passage. After being dragged by the plough, Yamunā makes her speech as quoted earlier, telling Baladeva: "I want the course I was assigned" (mārgam ādiștam icchāmi; Harivamśa 83.46c). This demand stretches the metaphor, since it is made after the event, and thus it makes sense if one thinks of Baladeva as moving a river, which he might then conceivably move back, but it does not make sense if one thinks of Baladeva's deed as a sexual act, for in that frame what is done cannot be undone. In the text, Baladeva is "tired and overcome with drunkenness" (madākrāntālaso; Harivamśsa 83.47d), and he says that Yamunā must stay where his plough has put her (lāingalākrșțamārgā tvam, 83.48a; eșa te

\footnotetext{
38 The contrast between benign (saumya) married goddesses and dangerous (raudra) independent ones has been discussed in the secondary literature. See, for example, Babb 1970; Foulston and Abbott 2009: 22-39. For critiques of this dichotomy, see Erndl 1993: 153-58; Balkaran 2019: 124-31.

39 The analogy between the annual and menstrual cycles is inexact because the annual cycle bears fruit within itself, whereas when a woman is with child (pre- and postpartum) the menstrual cycle is suspended.

40 On the feminine earth and the king in particular, see Derrett 1959; Hara 1973.

41 Application of this model to the birth of Rāma's wife Sītā in Vālmīki’s Rāmāyaṇa would be interesting but is not attempted here. Sītā's father Janaka says that she "sprang up behind my plow. I found her as I was clearing the field" (lāngalād utthitā mama I kșetram śodhayatā labdhvā; Rāmāyaṇa 1.65.14bc; Goldman 2005: 337). Janaka is a king, not a Vaiśya, but there is a royal ploughing festival: see Mahābhārata 3.241.24-243.10; von Simson 2009: 80-82. Sītā's birth-story is connected with her name, "Furrow" (compare Rg Veda 4.57.6-7), and with her earthly disappearance (Rämāyaṇa 7.88.9-20). The birth incident is mentioned also by Sītā herself and by Hanumat (Rāmāyaṇa 2.110.27-29, 5.14.16). See Bulcke 1952; Brockington 2007.

42 For hierarchical conflict between men in terms of "phallic aggression," see Assante 2017: 42.

43 According to the Viṣnu Purāna (but not the Harivaṃśa), when Revatî’s father offered her to him in marriage Baladeva noticed she was very tall (people were bigger in her day; compare Harivamśa 85.55), and so before marrying her he used the tip of his plough to reduce her in size. See Viṣnu Purāna 4.1.72 (uccapramānām iti tām avekșya svalāñgalāgreṇa sa tālaketuh I vināmayām āsa); Sanford 2012: 74-75.
} 
subhru saṃdeśah kathitah sāgaramgame | 83.49ab). By assigning her a new course he shows himself to be at least as powerful as whoever assigned her previous course. And so he is, for he is Viṣnu-Nārāyaṇa in both cases. He also says that Yamunā must "refresh this whole region of ours with the gift of your waters, for my sake" (imaṇ me priyadarśane I deśam ambupradānena nikhilạ̣ bhāvayasva naḥ || Harivamśa 83.48bcd). This apparent afterthought is the first mention of the possibility that Yamunā's new route might benefit anyone but himself. Perhaps at this point he might like to stay there at the party forever.

Then he says: "Flow in peace, distinguished river. Move along pleasantly, and my fame will surely endure as long as the worlds endure" (śāntim vraja mahābhāge gamyatām ca yathāsukham I lokā hi yāvat sthāsyanti tāvat sthāsyati me yaśaḥ || Harivamśa 83.49c-f).

Perhaps as a result of Baladeva's state of mind, the logical connection between Yamunā's making the best of it and Baladeva's long-lasting fame is slightly ambiguous here ("and" could be "for"). Baladeva's fame will surely endure among the cowherders, who approve and revere him for what he has done (Yamunākarșaṇam drṣțvā sarve te vrajavāsinah I sādhu sādhv iti rāmāya praṇāmam cakrire tadā ॥ Harivamśa 83.50). He seems to view his own future fame as connected to Yamunā and this incident, and to think this would be of some relevance to Yamunā. Does he suppose it would be a consolation to Yamunā that he is famous and that his fame depends upon her? Is she supposed to be happy because she can have greater fame because of Baladeva and this incident? The scene ends with no further word from her, and we are left to imagine that she discarded the woman's body (strīvigrahā; Harivamiśa 83.41c) and headed towards the sea, as she has been doing ever since.

Baladeva's bath is not described as such. According to the sexual-metaphorical interpretation, the bath would be a euphemism for something that has already happened in between the lines. No explanation is given for Baladeva's having wanted a bath in the first place. He is not there to bathe at a tirtha. It seems to have been a drunken whim, and this too strengthens the sexual-metaphorical interpretation. Water sports are a known trope in the erotic aspect of the literature. ${ }^{44}$

What of Baladeva's fame beyond the cowherds? For audiences of the Mahābhārata, including the Harivamísa, and for audiences of Purānas such as those mentioned in Vemsani's chart, his fame does not depend on this deed. It is only one of many deeds mentioned, for example, by Vaiśampāyana in Baladeva's chapter-long Māhātmya at Harivamiśa 90, which does not repeat those already mentioned in Mahäbhärata 1-18, and at the end of which he says there are more deeds that he has not mentioned, which Janamejaya should seek in the "old story collections" (yad akathitam ihādya karma te tad upalabhasva purānavistarāt ॥ Harivamís 90.19cd). Within Baladeva's present-day ritual and mythological tradition (as discussed by Sanford and reviewed above), his deed against Yamunā is more central to his role.

\footnotetext{
${ }^{44}$ See, for example, Mahābhārata 3.116.5-8; Harivamiśa 107.1-18; Kāmasūtra 1.4.26, 2.6.44. Although the analogy between bathing in a rajasvalā river and having sex with a rajasvala woman is not evident before the medieval period (Salomon 1984), the analogy between bathing and having sex may be older.
} 
In the Harivamśa (83.51), as soon as Baladeva has been applauded by the cowherds, he decides to head home to Mathurā, where Krṣna greets him kindly. Later, after the Yādava-Vṛṣnis move to Dvārakā, Baladeva marries Revatī (Harivamśa 86.80), a girl who was born there as a princess long ago but who visited Brahmā's heaven with her father and returned accelerated through time, to find the place full of Yādava-Vṛṇis (9.25-35). Baladeva enjoys his marriage with Revatī (reme rāmo 'pi dharmātmā revatyā sahitah sukhī ॥ Harivamiśa 9.28cd), and they have two sons, Niśatha and Ulmuka $(25.4$, 98.20). Baladeva seems to have married before Krṣna, as his marriage is mentioned before Krṣna's are. In that respect, he is not overstepped. The Bhāgavata Purāṇa sets the Yamunā incident after Baladeva's marriage to Revatī, and so effectively defuses the sexual aspect implied by the Harivamśa. In the Harivamsśa, the Yamunā scene occurs when Baladeva is still presumably sexually frustrated and at some level provoked by Kṛṇa's behavior with the gopiss.

This section has explored Baladeva in particular in connection with the quoted passage, pursuing the kind of interpretation suggested by Sanford 2000, as set up by the previous section on Krṣna and Baladeva. Overall, at this stage, the reader might or might not grant any, some, or significant credence to that sexual-metaphorical interpretation. But it bears the exploration in the Harivamśa context, particularly as Sanford was not speaking of the Harivamśa when she proposed it.

\section{"Misguided by Her Feminine Nature"}

Vaiśampāyana implies that Yamunā might have suffered a different fate had she responded differently to Baladeva's initial speech-that is, had she not been "misguided by her feminine nature" (strīsvabhāvena mohitā; Harivamiśa 83.29d). When Baladeva says "I want to bathe...come closer to me" (snätum icche mahānadi I ihaiva mābhigacchasva; Harivamśa 83.28bc), interpreted in light of what follows this is not just an invitation but also a command.

Is Janamejaya supposed to think that if Yamunā misunderstands Baladeva here, then that is because she is a woman? Is he also or instead supposed to think that Yamunā understands Baladeva, but that because she is a woman, she decides not to act on his words? If the latter, then which aspect of her inaction is Janamejaya supposed to focus on? For she neither travels to Baladeva at his request, nor at this point does she speak to him. There is physical and vocal inaction. Baladeva is roused to anger and action by this, but Vaiśampāyana does not say exactly what it was about it that angered him. Vaiśampāyana implies that a response might have been possible from Yamunā whereby she would neither give consent nor be forcibly taken without it. Is Janamejaya supposed to think that if Yamunā does not see that possibility, then that is because she is a woman? Is he also or instead supposed to think that she does see that possibility, but that because she is a woman, she decides not to pursue it? 
The text is mysterious as regards the precise deficiency denoted by the words strīsvabhāvena mohitā. ${ }^{45}$ But that deficiency is in any case labeled as the kind of deficiency one would expect a female to suffer from. Here Vaiśampāyana confirms the gendering of the incident, even if the verb muh, broadly meaning to be cognitively impaired or mistaken, is something that could apply to all beings in samsāra. Perhaps Janamejaya is supposed to understand Yamunā as drunk too, or even as more confusedly drunk because she is a woman. When a moment later she is being ploughed from one place to another, she is described as "like a drunk woman staggering along the royal road" (matteva kuṭilā nārī rājamārgeña gacchatī ॥ Harivamía 83.38cd), but it is not clear how close this simile would be. Baladeva is certainly drunk, whether or not he is really in samsāra. But once Vaiśampāyana invokes Yamunā's "feminine nature" there is a gendered stereotype in operation. The stereotype exculpates Yamunā for what happened, since she can only be what she is (that is, female), and it thus obviates what would have been an offensive conclusion, that Yamunā was somehow responsible for her own assault. But whatever else it might be, it is still a belittling, essentialist stereotype. The use of the words strīsvabhāvena mohitā to describe the speck that is Yamunā's deficiency might immediately draw the present-day reader's attention, by mirror image, to the $\log$ that is Baladeva's deficiency, ${ }^{46}$ and that might be described as his being misguided by his masculine nature. Appeal to Baladeva's essentially masculine nature, though not explicitly made in this scene, would be the same kind of cop-out as the appeal to Yamunā's essentially feminine nature.

The sensibilities of the present-day reader cannot be avoided. But without saying so explicitly, we have been trying to understand the Harivamśa scene by way of historical research, in its own context and in terms of how its recipients might realistically have understood it. Our attempts in this direction are halting, and perhaps ultimately hopeless, because however much associated data we might cull from other surviving texts from that period in order to help us join the dots, we do not know what the attitude of the average text-recipient was to those texts or this text. The listeners within the text-Janamejaya and then Śaunaka-hardly say anything, and both are elite figures. Perhaps most of the text's recipients knew it was riddled with offensive views but did not think that was quite reason enough to avoid it. We may appear to know more about the authors than about the recipients, because we have the work of the former but not the response of the latter; but attempting to interpret the work in terms of the authors without reference to the audience is very difficult and risks serious misunderstandings. In attempting to understand and translate the ancient authorial voice, the present-day commentator is

\footnotetext{
45 Ordinarily and primarily, the deficiency of strīsvabhāva would refer to the alleged fickleness and indiscriminate lustfulness of women (on which see Mahābhārata 13.38-43; Manusmriti 2.213-214, 8.77, 9.2, 9.14-21; Leslie 1989: 246-72); but this aspect of strīsvabhāva does not fit well here, since it is apparently Baladeva doing the desiring.

46 "And why worry about a speck in your friend's eye when you have a log in your own? How can you think of saying to your friend, 'Let me help you get rid of that speck in your eye,' when you can't see past the $\log$ in your own eye? Hypocrite! First get rid of the log in your own eye; then you will see well enough to deal with the speck in your friend's eye" (Matthew 7.3-5, "New Living Translation," http://nlt. to/Matthew.7.3-5/). The King James version (Blayney 1769) has "brother" instead of "friend."
} 
prey to all kinds of biases because of what it is currently fashionable, in his or her context, to talk about in what kinds of way. Meanwhile, sexual domination of females by males is one of the oldest recorded cultural tropes. Discursive response to male sexual violence is not a new phenomenon.

With these provisos in mind, is it possible to ask how we-massively displaced recipients of the text, trying, after suitable philological advice, to put ourselves in the place of the invisible ancient audience-are supposed to read and respond to the act that Baladeva drunkenly perpetrates upon the auspicious river goddess Yamunā with his plough? Our answers to the question of how we are supposed to respond would be speculative, ideological, and perhaps convincing and misleading in equal measure. We would be better off imagining what Janamejaya or Śaunaka might have thought about this story than imagining what the actual audience might have thought about it, because we at least know a bit about Janamejaya and Śaunaka from the text.

It might be easy for a present-day commentator convincingly to state that the authors of the Harivamśa were not enlightened in the ways that we are; that they took it for granted that men push women around and that female nature is deficient in ways that male nature is not; and that the degree of criticism that is thus directed at Baladeva through this scene is very slight. Those statements are certainly compatible with the Harivamśa 83 episode, but they do not really emerge from it. This is partly because neither Vaiśampāyana and Janamejaya nor Ugraśravas and Śaunaka are the text's author and audience: all four are characters within the text. Rather, such statements might be best understood in the present-day context where specialists in ancient literatures serve their audiences. But where academic service is to provide knowledge, the text's authorial service was to provide literatureliterature that is still literature and still art, and that in that respect need not tell the audience exactly what to think about it. Ambiguity is part of the point. But Baladeva does not respond well to Yamunā's ambiguity.

\section{Conclusion}

This article has contributed to a deep reading of the interactions between Baladeva and Yamunā in Harivamiśa 83. It has introduced and presented the text of the episode in English translation and discussed previous studies of it. It has explained how there are data problems with the mythological and the socio-historical interpretations of this scene, and hence it has explored and expanded upon a sexualmetaphorical interpretation suggested by Sanford 2000, which is effectively a literary interpretation that can be pursued on the basis of the textual data. The article has not sought to prove that interpretation, but hopefully readers will not consider the subject matter too distasteful to take it seriously.

A nuanced reading of Harivamśa 83 must recognize gender and sexual power dynamics as definitive of the scene. For clarity, it is also important to see how these dynamics tie into the mythology of agriculture, which is not necessarily in the way one might expect. In the end, as far as the scene in the Harivamśa is concerned, one must attend to the sexual undertones and to the protest lodged in Yamunā's speech. 
This article has shown that if one thinks of Baladeva and Krṣna as human-which they are, notwithstanding their simultaneous divinity-then the narrative context and poetic content provide support for a grimly plausible psychosexual drama that plays out alongside the surface-level event at Harivamiśa 83. A scenario is evoked in which Baladeva, at the drunken end of his visit to Vṛndāvana, sexually assaults a woman who has not made herself available. This aspect does not conflict or compete with the surface-level event of Baladeva's moving the river; it complements it and any interpretations that prioritize it. You may say, for example, that the scene in which Baladeva moves the Yamunā is there at this juncture in the narrative in order to complement Krṣṇa's movement of the Yādava-Vṛ̣ṇi people, with Yamunā symbolically being moved hundreds of miles to Dvārakā. But recognizing and accommodating the sexual drama are requirements for any complete interpretation.

Open Access This article is licensed under a Creative Commons Attribution 4.0 International License, which permits use, sharing, adaptation, distribution and reproduction in any medium or format, as long as you give appropriate credit to the original author(s) and the source, provide a link to the Creative Commons licence, and indicate if changes were made. The images or other third party material in this article are included in the article's Creative Commons licence, unless indicated otherwise in a credit line to the material. If material is not included in the article's Creative Commons licence and your intended use is not permitted by statutory regulation or exceeds the permitted use, you will need to obtain permission directly from the copyright holder. To view a copy of this licence, visit http:// creativecommons.org/licenses/by/4.0/.

\section{References}

Adluri, Vishwa and Joydeep Bagchee. 2018. Philology and Criticism: A Guide to Mahābhārata Textual Criticism. London: Anthem Press.

Asher, Frederick M. 1980. The Art of Eastern India, 300-800. Minneapolis: University of Minnesota Press.

Assante, Julia. 2017. "Men Looking at Men: The Homoerotics of Power in the State Arts of Assyria." In Ilona Zsolnay, ed., Being a Man: Negotiating Ancient Constructs of Masculinity, 42-82. London: Routledge.

Babb, Lawrence A. 1970. "Marriage and Malevolence: The Uses of Sexual Opposition in a Hindu Pantheon." Ethnology 9, 2: 137-48.

Balkaran, Raj. 2019. The Goddess and the King in Indian Myth: Ring Composition, Royal Power, and the Dharmic Double Helix. London: Routledge.

Bhāgavata Purāṇa. See Edwin F. Bryant.

Bigger, Andreas. 1998. Balarāma im Mahābhārata: Seine Darstellung im Rahmen des Textes und seiner Entwicklung. [Includes "English Summary," 157-66.] Wiesbaden: Harrassowitz Verlag.

Blayney, Benjamin, ed. 1769. The Holy Bible, Containing the Old and New Testaments: Translated out of the Original Tongues. Oxford: Oxford University Press.

Bowles, Adam. 2018. "Law During Emergencies: Apaddharma." In Patrick Olivelle and Donald R. Davis, Jr., eds., Hindu Law: A New History of Dharmaśāstra, 245-56. Oxford: Oxford University Press.

Brockington, John. 2007. "Sītā Janakātmajā.” Rocznik Orientalistyczny 60, 2: 82-89.

Brodbeck, Simon. 2009. The Mahābhārata Patriline: Gender, Culture, and the Royal Hereditary. Farnham: Ashgate.

Brodbeck, Simon. 2012. "On the Lineal Significance of the Rājasūya in the Mahābhārata." Indologica Taurinensia 38: 27-63.

Brodbeck, Simon. 2016. "Upākhyānas and the Harivaṃśa." In Vishwa Adluri and Joydeep Bagchee, eds., Argument and Design: The Unity of the Mahābhārata, 388-427. Leiden: Brill. 
Brodbeck, Simon, trans. 2017. "Libretto for Viśvāmitra and Nandin̄̄." Asian Literature and Translation 4, 1: $17-31$.

Brodbeck, Simon, trans. 2019. Krishna's Lineage: The Harivamsha of Vyāsa's Mahābhārata. New York: Oxford University Press.

Bryant, Edwin F., ed. and trans. 2003. Krishna: The Beautiful Legend of God. Śrīmad Bhāgavata Purāna, Book X, with Chapters 1, 6 and 29-31 from Book XI. London: Penguin Books.

van Buitenen, J. A. B., trans. 1973. The Mahābhārata. Volume One: Book 1, the Book of the Beginning. Chicago: University of Chicago Press.

van Buitenen, J. A. B., trans. 1975. The Mahābhārata. Volume Two: Book 2, the Book of the Assembly Hall; Book 3, the Book of the Forest. Chicago: University of Chicago Press.

Bulcke, Camille. 1952. "La naissance de Sītā.” Bulletin de l'École française d'Extrême-Orient 46, 1: 10717.

Carstairs, G. Morris. 1957. The Twice-Born: A Study of a Community of High-Caste Hindus. London: Hogarth Press.

Cendrars, Blaise. 1972 [1948]. Planus (trans. Nina Rootes). London: Peter Owen.

Coleman, Tracy. 2010. "Viraha-Bhakti and Strīdharma: Re-Reading the Story of Krṣna and the Gopīs in the Harivamiśa and the Bhāgavata Purāna." Journal of the American Oriental Society 130, 3: 385412.

Couture, André. 2015. "Cowherd-Settlements and Forests in Three Ancient Versions of Krṣnạ’s Childhood." In Couture, Kṛṣna in the Harivamía. Volume One: The Wonderful Play of a Cosmic Child, 163-79. New Delhi: D.K. Printworld.

Couture, André. 2017. "Sam̉karșaṇa and His Relationships with Kṛ̣ṇa: Presence and Absence, Coming Together and Moving Apart." In Couture, Kṛṣna in the Harivamśa. Volume Two: The Greatest of All Sovereigns and Masters, 217-92. New Delhi: D.K. Printworld.

Dandekar, R. N., gen. ed. 1971-76. The Mahābhārata: Text as Constituted in Its Critical Edition. 5 volumes. Poona: Bhandarkar Oriental Research Institute.

Dandekar, R. N. 1975-76. "The Beginnings of Vaiṣnavism.” Indologica Taurinensia 3-4: 169-86.

Darian, Steven G. 1978. The Ganges in Myth and History. Honolulu: University Press of Hawaii.

Derrett, J. Duncan R. 1959. "Bhü-Bharaṇa, Bhū-Pālana, Bhū-Bhojana: An Indian Conundrum.” Bulletin of the School of Oriental and African Studies 22, 1: 108-23.

Doniger, Wendy and Sudhir Kakar, trans. 2002. Vatsyayana Mallanaga: Kamasutra. A New, Complete English Translation of the Sanskrit Text, with Excerpts from the Sanskrit Jayamangala Commentary of Yashodhara Indrapada, the Hindi Jaya Commentary of Devadatta Shastri, and Explanatory Notes by the Translators. New York: Oxford University Press.

Eck, Diana L. 1996. "The Goddess Ganges in Hindu Sacred Geography." In John Stratton Hawley and Donna Marie Wulff, eds., Devī: Goddesses of India, 137-53. Berkeley: University of California Press.

Erndl, Kathleen M. 1993. Victory to the Mother: The Hindu Goddess of Northwest India in Myth, Ritual, and Symbol. New York: Oxford University Press.

Feldhaus, Anne. 1995. Water and Womanhood: Religious Meanings of Rivers in Maharashtra. New York: Oxford University Press.

Feller, Danielle. 1999. Review of Andreas Bigger's Balarāma im Mahābhārata: Seine Darstellung im Rahmen des Textes und seiner Entwicklung. Asiatische Studien / Études asiatiques 53, 3: 811-14.

Fitzgerald, James L., trans. 2004. The Mahābhārata. Volume Seven: Book 11, the Book of the Women; Book 12, the Book of Peace, Part One. Chicago: University of Chicago Press.

Fitzgerald, James L. 2007. "Bhīṣma Beyond Freud: Bhīṣma in the Mahābhārata." In Simon Brodbeck and Brian Black, eds., Gender and Narrative in the Mahäbhārata, 189-207. London: Routledge.

Foulston, Lynn and Stuart Abbott. 2009. Hindu Goddesses: Beliefs and Practices. Eastbourne: Sussex Academic Press.

Goldman, Robert P. 1978. "Fathers, Sons and Gurus: Oedipal Conflict in the Sanskrit Epics." Journal of Indian Philosophy 6, 4: 325-92.

Goldman, Robert P. 1980. "Rāmaḥ Sahalakșmaṇaḥ: Psychological and Literary Aspects of the Composite Hero of Vālmīki's Rāmāyaña." Journal of Indian Philosophy 8, 2: 149-89.

Goldman, Robert P., trans. 2005. Rāmāyaṇa Book One: Boyhood, by Vālmīki. Clay Sanskrit Library. New York: New York University Press and JJC Foundation.

Gonda, Jan. 1993 [1954]. Aspects of Early Viṣnuism. New Delhi: Motilal Banarsidass.

Griffin, Susan. 1978. Woman and Nature: The Roaring Inside Her. New York: Harper \& Row. 
Haberman, David L. 2006. River of Love in an Age of Pollution: The Yamuna River of Northern India. Berkeley: University of California Press.

Hara, Minoru. 1973. "The King as a Husband of the Earth (Mahi-Pati)." Asiatische Studien / Études asiatiques 27, 2: 97-114.

Harivamśa. See Parashuram Lakshman Vaidya.

Heenan, Melanie. 2003. "Reconstituting the 'Relevance' of Women's Sexual Histories in Rape Trials." Women Against Violence 13: 4-17.

Herman, Phyllis K. 1979. "Ideal Kingship and the Feminine Power: A Study of the Depiction of Ramarajya in the Valmiki Ramayana." Ph.D. dissertation, University of California, Los Angeles.

Hiltebeitel, Alf. 2001. Rethinking the Mahābhārata: A Reader's Guide to the Education of the Dharma King. Chicago: University of Chicago Press.

Jaiswal, Suvira. 1967. The Origin and Development of Vaiṣnavism (Vaiṣnavism from 200 B.C. to A.D. 500). New Delhi: Munshiram Manoharlal.

Jamison, Stephanie W. and Joel P. Brereton, trans. 2017. The Rigveda: The Earliest Religious Poetry of India. 3 volumes. New York: Oxford University Press.

Joshi, N. P. 1979. Iconography of Balarāma. New Delhi: Abhinav Publications.

Kāmasūtra. See Wendy Doniger and Sudhir Kakar.

Kane, Pandurang Vaman. 1974 [1941]. History of Dharmaśāstra (Ancient and Mediceval Religious and Civil Law). Volume Two, Part One. Poona: Bhandarkar Oriental Research Institute.

Kessler, Anne. 2009. "Yakșas and Yakșin̄īs." In Knut A. Jacobsen, gen. ed., Brill's Encyclopedia of Hinduism, 1: 801-6. Leiden: Brill.

King, Anna S. 2005. "The Ganga: Waters of Devotion.” In Anna S. King and John Brockington, eds., The Intimate Other: Love Divine in Indic Religions, 153-93. New Delhi: Orient Longman.

Kulikov, Leonid. 2017. "Yamī, Twin-Sister of Yama: Demigoddess or Half-Human? Vedic Origins and Further Developments in Purāṇas (from Demonic to Human Sexuality)." Paper presented at the Eighth Dubrovnik International Conference on the Sanskrit Epics and Purāṇas, September 11-16, 2017, Dubrovnik, Croatia.

Kumar, Bidisha and George James. 2009. "Yamunā." In Knut A. Jacobsen, gen. ed., Brill's Encyclopedia of Hinduism, 1: 817-21. Leiden: Brill.

Langlois, M. A., trans. 1834. Harivansa ou Histoire de la famille de Hari, ouvrage formant un appendice du Mahabharata. Volume One. London: Oriental Translation Fund of Great Britain and Ireland.

Lassen, Christian. 1867 [1847]. Indische Alterthumskunde. Volume One. Leipzig: L. A. Kittler.

Leslie, I. Julia. 1989. The Perfect Wife: The Orthodox Hindu Woman According to the Stridharmapaddhati of Tryambakayajvan. New Delhi: Oxford University Press.

Levanon, Liat. 2012. "Sexual History Evidence in Cases of Sexual Assault: A Critical Re-Evaluation." University of Toronto Law Journal 62, 4: 609-51.

Mahābhārata. See R. N. Dandekar (1971-76).

Manusmrti. See Patrick Olivelle.

Matchett, Freda. 2001. Kṛṣna: Lord or Avatāra? The Relationship between Krṣnna and Viṣnu in the Context of the Avatāra Myth as Presented by the Harivamiśa, the Viṣnupurāna and the Bhāgavatapurāna. London: Routledge.

McGlynn, Clare. 2017. "Rape Trials and Sexual History Evidence: Reforming the Law on Third-Party Evidence." Journal of Criminal Law 81, 5: 367-92.

Mehendale, M. A. 1984 [1982]. "Nemesis and Some Mahābhārata Episodes." In S. D. Joshi, ed., Amritadhārā: Professor R. N. Dandekar Felicitation Volume, 273-79. New Delhi: Ajanta.

Merchant, Carolyn. 1989 [1980]. The Death of Nature: Women, Ecology and the Scientific Revolution. San Francisco: HarperCollins.

Monier-Williams, Monier. 2005 [1899]. A Sanskrit-English Dictionary, Etymologically and Philologically Arranged, with Special Reference to Cognate Indo-European Languages. New Delhi: Motilal Banarsidass.

Olivelle, Patrick, ed. and trans., with the editorial assistance of Suman Olivelle. 2005. Manu's Code of Law: A Critical Edition and Translation of the Mānava-Dharmaśāstra. New Delhi: Oxford University Press.

Pathak, M. M., ed. 1997-99. The Critical Edition of the Viṣnupurāṇam. 2 volumes. Vadodara: Oriental Institute.

Rāmāyaṇa. See R. T. Vyas.

Rg Veda. Available at: http://www.sacred-texts.com/hin/rvsan/index.htm (accessed January 8, 2020). 
Salomon, Richard. 1984. "Legal and Symbolic Significance of the 'Menstrual Pollution' of Rivers." In Richard W. Lariviere, ed., Studies in Dharmaśāstra, 153-78. Calcutta: Firma KLM.

Sanford, A. Whitney. 2000. "Uneasy Partners: Balarāma as Embodiment of Wilderness." In Mariola Offredi, ed., The Banyan Tree: Essays on Early Literature in New Indo-Aryan Languages (Proceedings of the Seventh International Conference on Early Literature in New Indo-Aryan Languages, Venice, 1997), 2: 363-87. New Delhi: Manohar.

Sanford, A. Whitney. 2005. "Holī Through Daūjī’s Eyes: Alternate Views of Krishna and Balarāma in Daūjī.” In Guy L. Beck, ed., Alternative Krishnas: Regional and Vernacular Variations on a Hindu Deity, 91-112. Albany: State University of New York Press.

Sanford, A. Whitney. 2012. Growing Stories from India: Religion and the Fate of Agriculture. Lexington: University Press of Kentucky.

Schmid, Charlotte. 2010. Le Don de voir: Premières représentations krishnaïtes de la région de Mathurā. Paris: École française d'Extrême-Orient.

Sharma, Arvind. 1986. "The Significance of Viṣnu Reclining on the Serpent." Religion 16, 2: 101-14.

von Simson, Georg. 2009. "The Lunar Character of Balarāma/Samkarșaṇa." In Petteri Koskikallio, ed., Parallels and Comparisons: Proceedings of the Fourth Dubrovnik International Conference on the Sanskrit Epics and Purānas, September 2005, 67-87. Zagreb: Croatian Academy of Sciences and Arts.

Singer, Peter. 2018. "Balarāma Drags the River Yamunā." Available at: https://sanskritreadingroom. wordpress.com/2018/02/01/balarama-drags-the-river-yamuna/ (accessed January 8, 2020).

Srinivasan, Doris Meth. 2008. "Samkarșana/Balarāma and the Mountain: A New Attribute." In Claudine Bautze-Picron, ed., Religion and Art: New Issues in Indian Iconography and Iconology, 93-104. London: British Association for South Asian Studies.

Srinivasan, Doris Meth. 2016. Listening to Icons. Volume One: Indian Iconographic and Iconological Studies. New Delhi: Aryan Books International.

von Stietencron, Heinrich. 2010 [1972]. Gañgā and Yamunā: River Goddesses and Their Symbolism in Indian Temples (trans. Mitch Cohen). New Delhi: Permanent Black.

Sutherland, Gail Hinich. 1991. The Disguises of the Demon: The Development of the Yakșa in Hinduism and Buddhism. Albany: State University of New York Press.

Vaidya, Parashuram Lakshman, ed. 1969. The Harivamisa, Being the Khila or Supplement to the Mahābhārata, for the First Time Critically Edited. Volume One: Introduction, Critical Text and Notes. Poona: Bhandarkar Oriental Research Institute.

Vemsani, Lavanya. 2006. Hindu and Jain Mythology of Balarāma: Change and Continuity in an Early Indian Cult. Lewiston: Edwin Mellen Press.

Vemsani, Lavanya. 2016. Balarāma in Hindu and Jain Mythology: Brother of Krishna in Classical Texts and History. USA: Createspace Independent Publishing Platform.

Viṣnu Purāṇa. See M. M. Pathak.

Vyas, R. T., gen. ed. 1992. Vālmīki Rāmāyaṇa: Text as Constituted in Its Critical Edition. Vadodara: Oriental Institute.

Wilson, H. H., trans. 1840. The Vishńu Puráńa: A System of Hindu Mythology and Tradition. London: John Murray.

\section{Publisher's Note}

Springer Nature remains neutral with regard to jurisdictional claims in published maps and institutional affiliations. 